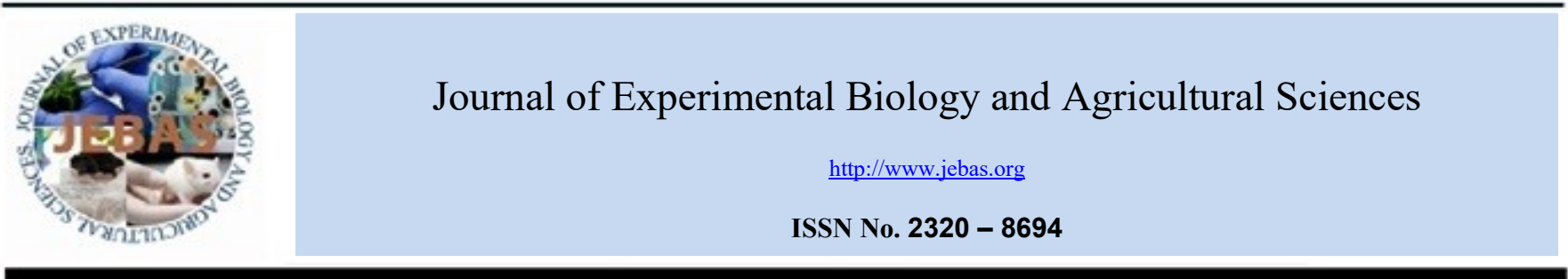

\title{
VALIDATION OF MOLECULAR MARKERS LINKED TO QUALITY TRAITS IN INDIAN MUSTARD (Brassica juncea L)
}

\author{
Vijay Veer Singh*, Monika, Ibandalin Mawlong, Priyamedha, Neeraj Gurjar, Balbeer, S \\ Kulshreshtha, M L Meena, Pankaj Sharma and P K Rai
}

ICAR-Directorate of Rapeseed-Mustard Research, Bharatpur (Raj) -India 321303

Received - March 23, 2020; Revision - May 29, 2020; Accepted - June 15, 2020

Available Online - June 25, 2020

DOI: http://dx.doi.org/10.18006/2020.8(3).233.240

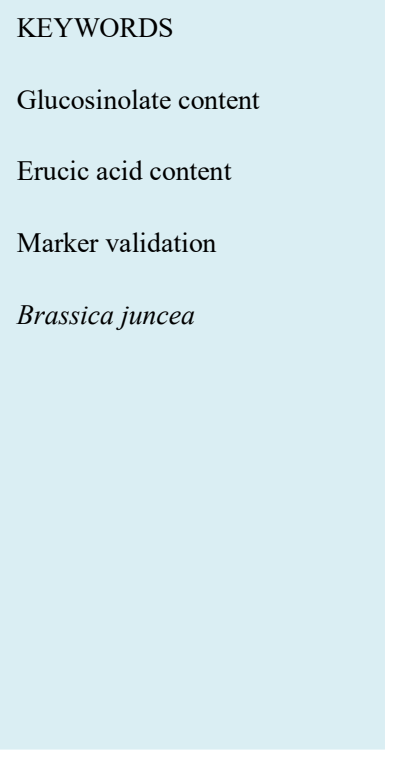

\begin{abstract}
Present study consisted of parents and their generations viz; P1 (NRCHB-101, DRMR 150-35), P2 (PDZ-1, Heera and RLC-3), F 's (NRCHB-101xPDZ-1, NRCHB-101xHeera, NRCHB-101xRLC-3, DRMR-15035xPDZ-1, DRMR-150-35xHeera and DRMR150-35xRLC-3), and their back crosses $\left(\mathrm{BC}_{1} \mathrm{~F}_{1}\right.$ and $\left.\mathrm{BC}_{2} \mathrm{~F}_{1}\right)$ with a view to validate molecular markers linked to quality traits (low glucosinolate and erucic acid) in Indian mustard. The phenotyping of parents and backcross progenies was performed for estimation of total seed glucosinolate content and erucic acid content using UV-Vis spectrophotometer and Gas chromatography respectively. Parents were also validated for low erucic acid trait using set of two CAPS markers for FAE 1.1 gene and all parental genotypes under study generated fragments of expected size for each CAPS maker. The CAPS markers for FAE1.1 gene amplified 432 bp and 427 bp fragments for E1 marker and E2 marker respectively. Markers linked to low glucosinolate showed polymorphism among donor and recipient parents. The genotyping among backcross progenies revealed heterozygous banding pattern with markers linked to low glucosinolate and erucic acid traits. It was concluded that total glucosinolate content of most of the samples of backcross generations were in the range of $50-85 \mu \mathrm{mol} / \mathrm{g}$ defatted seed meal whereas erucic acid content ranged $10.75 \%$ to $33.18 \%$. Validation of these molecular markers linked to quality traits can be used efficiently for MAS by mustard breeders for improvement of oil quality in breeding programme.
\end{abstract}

* Corresponding author

E-mail: singhvijayveer71@gmail.com (Vijay Veer Singh)

Peer review under responsibility of Journal of Experimental Biology and Agricultural Sciences.

Production and Hosting by Horizon Publisher India [HPI] (http://www.horizonpublisherindia.in/).

All rights reserved.
All the articles published by Journal of Experimental Biology and Agricultural Sciences are licensed under a Creative Commons Attribution-NonCommercial 4.0 International License Based on a work at www.jebas.org.

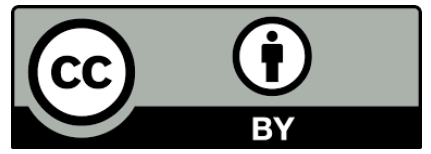




\section{Introduction}

Indian mustard (Brassica juncea (L.) Czern and Coss) is one of the most important oilseed among rapeseed-mustard group of crops. It is cultivated along with four other closely related oilseed species viz. B. rapa, B. napus, B.carinata and Eruca sativa. Over the past couple of decades, these crops have become one of the most important sources of vegetable oil in the world. Brassicas oilseed share second (25\%) after soybean (38\%) in total oilseeds production, however, it stands first $(23 \%)$ in edible oil production in the country (Jat et al., 2019). Continuous improvement in rapeseed-mustard has resulted in nutritionally superior edible oil and meal as an important source of protein in animal feed (Jesch \& Carr, 2017). Mustard oil is an important dietary component and its quality is defined by improved fatty acid profile of oil with low erucic acid content (Pham \& Pham, 2012). Quality of its seed meal is determined by low glucosinolate content and a large group of secondary plant metabolites derived from different amino acids such as methionine, phenylalanine and tryptophan (Priyamedha et al., 2015). The oil extracted from Indian mustard has lowest concentration (approx.7\%) of saturated fatty acids with higher proportion of unsaturated fatty acids viz. oleic (C18:1), linoleic (C18:2) and linolenic (C18:3) acid. Of the total fatty acids, there is predominance of erucic acid (C22:1) fraction (35.7-51.4\%) along with higher glucosinolate content in seed meal in traditional varieties of Indian mustard (Chauhan et al., 2007). Consumption of higher amount of mustard oil having high erucic acid $(>20 \%)$, causes myocardial fibrosis, impaired myocardial conductance, lipidosis etc. and also increases blood cholesterol (Ackman et al., 1977; Chien et al, 1983). Therefore, reduction in erucic acid is one of the important objectives in quality amelioration of Indian mustard seed oil. It is desirable to increase oleic acid content in oil as it is less vulnerable to oxidations and also it is very much effective in reducing total cholesterol level of blood (Mattson \& Grundy, 1985; Liu et al., 2003).

Efforts are underway towards development of low erucic and/or low glucosinolate and high yielding varieties through deployment of genes responsible for quality traits into high yielding varieties. The most convenient and authentic way for pyramiding genes responsible for low erucic and low glucosinolate is through marker assisted breeding (MAS). MAS is the selection for a trait based on genotype using associated markers rather than the phenotype of the trait (Foolad \& Sharma, 2005). MAS is highly beneficial in achieving the same breeding progress in a much shorter time than through conventional breeding as well as pyramiding combinations of genes that could not be readily combined through other means (Xu \& Crouch, 2008).

Attempts have been made for identification of molecular markers linked to the traits like low erucic and low glucosinolate by various scientists (Gupta et al., 2004; Ramchiary et al., 2007; Hasan et al.,
2008; Bisht et al., 2009). Since then various studies have been conducted to validate these markers in Indian mustard. The present study was undertaken to employ the quality trait linked markers in pyramiding of the genes responsible for low erucic and low glucosinolate content in different high yielding varieties through marker assisted backcross breeding approach involving different single/ double low lines/varieties.

\section{Materials and Methods}

\subsection{Genetic material and growth conditions}

The field studies were carried out during rabi cropping seasons of 2015 to 2017 (October to March) for consecutive three years at ICAR-Directorate of Rapeseed Mustard Research Bharatpur, India $\left(27^{\circ} 11^{\prime} \mathrm{N}\right.$ Lattitude and $77^{\circ} 27^{\prime} \mathrm{E}$ Longitude and $180 \mathrm{~m}$ above sea level).

The materials for the present investigation consisted of parents and their generations viz; P1 (NRCHB 101, DRMR 150-35), P2 (PDZ 1, Heera and RLC-3), $\mathrm{F}_{1}$ 's (NRCHB101xPDZ-1, NRCHB101xHeera, NRCHB101xRLC-3, DRMR150-35xPDZ-1, DRMR 150-35xHeera and DRMR150-35xRLC-3), and their back crosses $\left(\mathrm{BC}_{1} \mathrm{~F}_{1}\right.$ and $\left.\mathrm{BC}_{2} \mathrm{~F}_{1}\right)$. NRCHB101 and DRMR150-35 are high yielding varieties with high glucosinolate and high erucic acid content were taken as recipient parents whereas PDZ-1,Heera and RLC-3 are varieties/genotypes with low glucosinolate and low erucic acid were taken as donor parents.

Backcross progenies i.e. $\mathrm{BC}_{1} \mathrm{~F}_{1}, \mathrm{BC}_{2} \mathrm{~F}_{1}$ along with their parents (NRCHB101, DRMR150-35, PDZ-1, RLC-3 and Heera) were sown during rabi 2016-17 and 2017-18 respectively. The seed were sown in plot consisting 5 rows of length $5 \mathrm{~m}$ each. The rows were spaced $30 \mathrm{~cm}$ apart with plant to plant spacing of $10 \mathrm{~cm}$. For raising a healthy crop recommended agronomic practices were applied.

\subsection{Development of backcross populations}

Two high glucosinolate and erucic acid varieties of $B$. juncea (NRCHB101 and DRMR150-35) were used as female parent and crossed with low glucosinolate and erucic acid donors (PDZ-1, RLC-3 and Heera). During Rabi season 2015-16, emasculation of selected buds was performed $24-48 \mathrm{hr}$ before anthesis, and fresh pollen from the donor parent was applied to the stigmas. The flowers were then protected with paper bags and labelled. The resultant $F_{1}$ plants thus obtained were backcrossed with recurrent parent to produce $\mathrm{BC}_{1} \mathrm{~F}_{1}$ generations at offseason nursery IARIregional station, Wellington, Tamil Nadu during Kharif 2016.The $\mathrm{BC}_{1} \mathrm{~F}_{1}$ generation plants were raised in rabi 2016-17 and were further backcrossed to recipient parent of each cross to produce $\mathrm{BC}_{2} \mathrm{~F}_{1}$ generation. The $\mathrm{BC}_{2} \mathrm{~F}_{1}$ generation plants were raised in rabi 2017-18 and were further backcrossed for generation advancement. 
A negative selection based on visual observations was conducted among all the $\mathrm{BC}_{1} \mathrm{~F}_{1}$ and $\mathrm{BC}_{2} \mathrm{~F}_{1}$ plant generation in order to eliminate plants or lines resembling morphological characteristics with donor parents that are PDZ-1, RLC-3 and Heera.Each generation plants i.e. $\mathrm{F}_{1}, \mathrm{BC}_{1} \mathrm{~F}_{1}, \mathrm{BC}_{2} \mathrm{~F}_{1}$ were validated using molecular markers linked to quality traits in their subsequent sowing seasons.

\subsection{Molecular analysis}

Genomic DNA was isolated from fresh, young and healthy leaves using the standard cetyl trimethyl ammonium bromide (CTAB) protocol (Doyle \& Doyle., 1990). Purification of DNA was carried out by adding $10 \mathrm{~g} / 100 \mathrm{ml}$ of RNase to the sample vial containing crude DNA at a proportion of $3 \mu 1 / 100 \mathrm{ml}$.DNA quantification was done by using agrose at a concentration of $0.8 \%$. For amplification of parents and backcross progenies i.e. $\mathrm{BC}_{1} \mathrm{~F}_{1}$ and $\mathrm{BC}_{2} \mathrm{~F}_{1}$, a set of five low glucosinolate trait linked polymorphic markers i.e. (GER1 (Q1); Myb28 (Q2); At5g41 (Q3); At5GAJ67 (Q4) and GER-5 (Q5) (Bisht et al., 2009; Singh et al., 2018) and a set of two low erucic acid trait linked CAPS markers that is E1 and E2 for gene FAE1.1(Gupta et al., 2004) (Table 1,2) were used. PCR assay was carried out in 96-well Fast Thermal Cycler (PE Applied Biosystems, USA) in a total volume of $10 \mu \mathrm{l}$ reaction mixture. Each reaction mixture contained genomic DNA of $25 \mathrm{ng}$ as templete, 1.0 unit Taq DNA polymerase (Dream Taq), $20 \mathrm{ng}$ each forward and reverse primer ,10X Dream Taq PCR assay buffer with $1.5 \mathrm{mM} \mathrm{MgCl}_{2}, 0.2 \mu \mathrm{l}$ dNTPs mix and reaction volume was made up to $10 \mu \mathrm{l}$ by adding nuclease free water. Amplification was carried out according to the following set up: The cycle was repeated 35 times after initial denaturation at $94^{\circ} \mathrm{C}$ for $5 \mathrm{~min}$. Each cycle consists of cyclic denaturation at $94^{\circ} \mathrm{C}$ for $45 \mathrm{~s}$, annealing temperature at $55-58^{\circ} \mathrm{C}$ for $50 \mathrm{~s}$ and the primer extension at $72^{\circ} \mathrm{C}$ for $1 \mathrm{~min}$ and final extension of $72^{\circ} \mathrm{C}$ for $7 \mathrm{~min}$ followed by incubation at $4^{\circ} \mathrm{C}$. The PCR product bands resolution was done electrophoretically on $2.5 \%$ agarose gel containing $0.01 \%$ ethidium bromide prepared in 1x TAE (Tris-Acetic acid-EDTA) buffer. 100bp DNA Ladder (Thermo Scientific) was used as standard to compare PCR amplicon band sizes. The gel was run for $2.5 \mathrm{~h}$ at $120 \mathrm{~V}$. After

Table 1 Details of the molecular markers and restriction enzymes used in validation of erucic acid

\begin{tabular}{|c|c|c|c|c|c|c|c|c|c|c|}
\hline \multirow[b]{2}{*}{ S.No. } & \multirow[b]{2}{*}{ Gene } & \multirow{2}{*}{$\begin{array}{c}\text { Chromosome } \\
\text { location of } \\
\text { FAE } 1.1\end{array}$} & \multirow{2}{*}{$\begin{array}{l}\text { Molecular } \\
\text { Marker } \\
\text { code }\end{array}$} & \multirow{2}{*}{$\begin{array}{l}\text { Molecular } \\
\text { marker } \\
\text { name }\end{array}$} & \multirow[b]{2}{*}{ Nucleotide sequence $\left(5^{\prime} \rightarrow 3^{\prime}\right)$} & \multirow[b]{2}{*}{$\begin{array}{l}\mathrm{Tm} \\
\left({ }^{\circ} \mathrm{C}\right)\end{array}$} & \multicolumn{4}{|c|}{ Size of band (bp) } \\
\hline & & & & & & & $\begin{array}{l}\text { Restriction } \\
\text { enzyme }\end{array}$ & $\begin{array}{l}\text { Amplicon } \\
\text { size (bp) }\end{array}$ & $\begin{array}{l}\text { High } \\
\text { E.A }\end{array}$ & $\begin{array}{l}\text { Low } \\
\text { E.A }\end{array}$ \\
\hline 1 & FAE1.1 & $\begin{array}{l}\text { LG17 in } \\
\text { B.juncea }\end{array}$ & E1 & $\begin{array}{l}\text { FAE II F } \\
\text { FAE II R }\end{array}$ & $\begin{array}{c}\text { TCGTGGCTTGACTTCTTGAG } \\
\text { GGACCTATTATCACCAGCGTAAA }\end{array}$ & 55 & Нру99I & 432 & $\begin{array}{l}432 \\
224 \\
198 \\
\end{array}$ & 432 \\
\hline 2 & $F A E 1.1$ & $\begin{array}{l}\text { (Gupta et } \\
\text { al.2004) }\end{array}$ & E2 & $\begin{array}{l}\text { FAE III F } \\
\text { FAE III R }\end{array}$ & $\begin{array}{l}\text { ACGTTAGGTCCGTTGATTCTTC } \\
\text { GGGTATCTGTCGATGCAATGT }\end{array}$ & 55 & $B g l I I$ & 427 & 427 & $\begin{array}{l}427 \\
209 \\
198\end{array}$ \\
\hline
\end{tabular}

Table 2 Details of glucosinolate QTLs linked markers used for validation

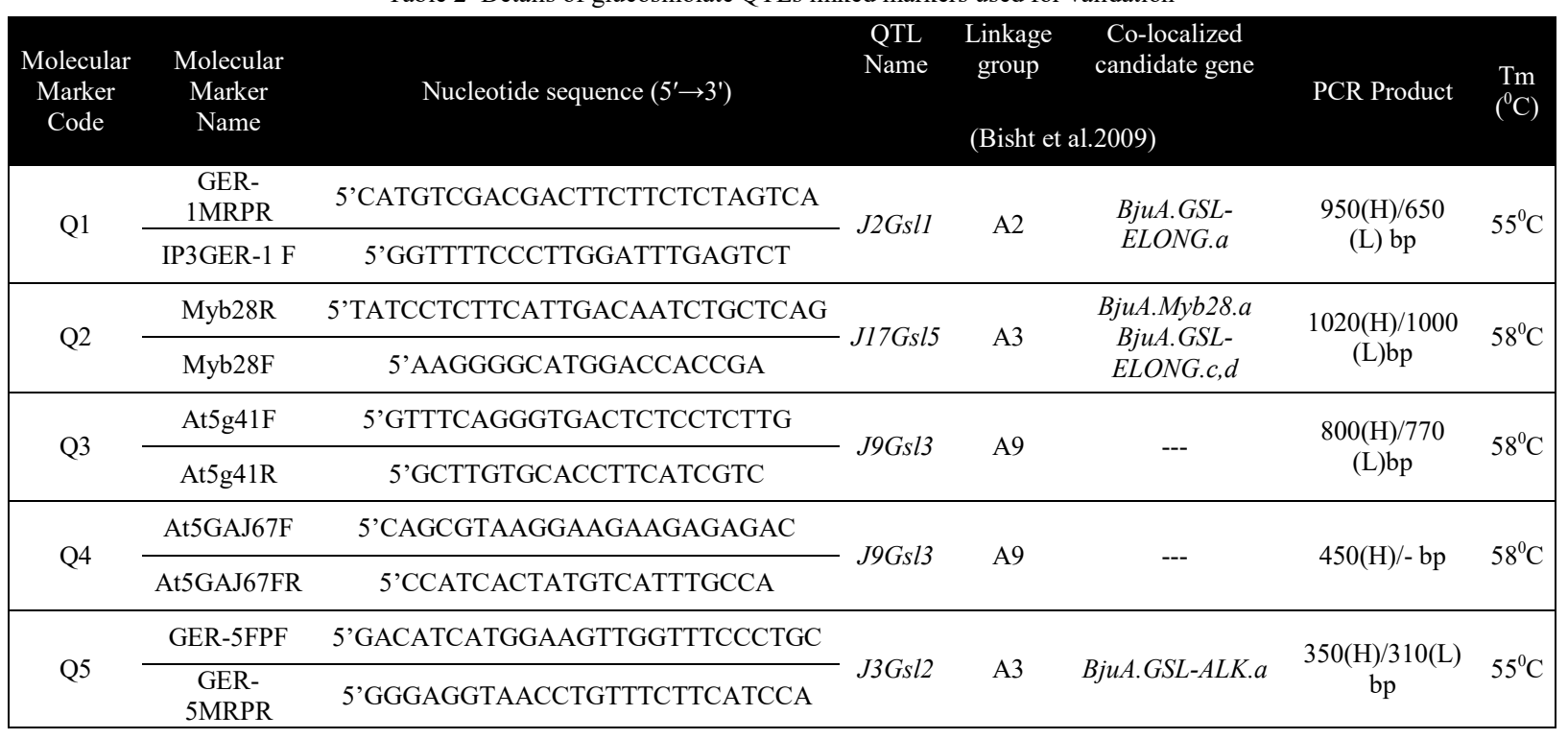

Journal of Experimental Biology and Agricultural Sciences http://www.jebas.org 
electrophoresis, the gel picture was visualized using gel 3 Results and Discussion

documentation system (IG/LHR, Syngene, UK).

\subsection{Total seed glucosinolate extraction and quantification}

Total glucosinolate was estimated in seeds of parents, $\mathrm{BC}_{1} \mathrm{~F}_{1}$ and $\mathrm{BC}_{2} \mathrm{~F}_{1}$ plants which were found low using molecular markers. Estimation of total glucosinolate content in defatted seed meal was carried out (Mawlong et al., 2017) as per standardized method. The absorbance was taken at $425 \mathrm{~nm}$ using a spectrophotometer (Labomed UV-VIS Double beam UVD-3500) after colour development due to complex formation between glucosinolates methanolic extract and sodium tetrachloropalladate solution. The absorbance so obtained was used in the predicted formula (Mawlong et al., 2017) to calculate total glucosinolate content;

Total glucosinolate concentration $(\mu \mathrm{mol} / \mathrm{g})=1.40+118.86 \times \mathrm{A}_{425}$

Whereas $\mathrm{A}_{425}=$ absorbance at 425 .

\subsection{Estimation of erucic acid content in seed oil}

Erucic acid estimation in seed oil of parents and backcross $\left(\mathrm{BC}_{1} \mathrm{~F}_{1}\right.$ and $\left.\mathrm{BC}_{2} \mathrm{~F}_{1}\right)$ generations was carried out by conducting fatty acid profiling using Gas Liquid Chromatography (GLC) according to the FAME (fatty acid methyl esters) method developed by Goli et al. (2008). Perkin Elmer Clarus 600 equipped with flame ionization detector (FID) was used for analysis of samples. Nitrogen gas was used as a carrier and the standardized temperature conditions of oven injector and detector were maintained at 230 to $250^{\circ} \mathrm{C}$ respectively. The peaks identification of FAME was conducted by comparing the retention time of the samples under analysis to that of control sample which were used as standards of erucic acid content and were subjected to similar separation conditions as that of samples under study. The erucic acid content obtained was expressed in form of percent total fatty acids.
3.1 Validation for glucosinolate and erucic acid content using linked markers

\subsection{1 $\mathrm{BC}_{1} \mathrm{~F}_{1}$ Generation}

Six $\mathrm{BC}_{1} \mathrm{~F}_{1}$ populations, developed from the cross NRCHB101×PDZ-1， NRCHB101×RLC-3， NRCHB101×Heera, DRMR150-35× PDZ-1, DRMR150-35× RLC-3, DRMR150$35 \times$ Heera, comprising of $76,52,80,84,100$ and 80 plants respectively, were genotyped for glucosinolate content. Out of these 472 plants, 75 plants were found to exhibit heterozygous banding pattern for all the three markers i.e. GER-1 (Q1); At5g41 (Q3); and GER-5 (Q5) (Figure 2 and 3). These 75 screened plants were further subjected to erucic acid validation using CAPS markers available for this study.

Out of these 75 plants, 64 plants were found with E1E1 genotype i.e. for high erucic acid (three fragments with E1 marker while single fragment for E2 marker), none of the individual plant showed e1e1 genotype i.e. for low erucic acid (single fragment with E1 marker while three fragments for E2 marker) and 11 were having E1e1 genotype i.e. intermediate ER (single fragment with E1 and E2 both the markers or three fragments with E1 marker and E2 marker both) (Table 3). These 11 plants which were exhibiting heterozygote banding pattern for FAE1.1 genes were selected for further backcrossing with recurrent parent. These 11 plants obtained after erucic acid validation were derived from the crosses DRMR150-35×PDZ-1, DRMR150-35× RLC-3, NRCHB $101 \times \mathrm{PDZ}-1$ and $\mathrm{NRCHB} 101 \times$ Heera. $\mathrm{BC}_{2} \mathrm{~F}_{1}$ generation derived from these four crosses were screened for quality traits (low glucosinolate and low erucic acid) using molecular markers as mentioned above.

Table 3 Genotyping of $\mathrm{BC}_{1} \mathrm{~F}_{1}, \mathrm{BC}_{2} \mathrm{~F}_{1}$ for glucosinolate trait and erucic acid.

\begin{tabular}{|c|c|c|c|c|c|c|c|}
\hline S.No & Cross name & $\begin{array}{l}\text { No.of plants } \\
\text { screened } \\
\quad\left(\mathrm{BC}_{1} \mathrm{~F}_{1}\right)\end{array}$ & $\begin{array}{l}\text { No.of plants } \\
\text { obtained } \\
\text { (using low } \\
\text { glucosinolate } \\
\text { markers) }\end{array}$ & $\begin{array}{l}\text { No.of plants } \\
\text { obtained } \\
\text { (using Erucic } \\
\text { acid markers) }\end{array}$ & $\begin{array}{l}\text { No.of plants } \\
\text { screened } \\
\left(\mathrm{BC}_{2} \mathrm{~F}_{1}\right)\end{array}$ & $\begin{array}{l}\text { No.of plants } \\
\text { obtained (using } \\
\text { low } \\
\text { glucosinolate } \\
\text { markers) }\end{array}$ & $\begin{array}{l}\text { No.of plants } \\
\text { obtained (using } \\
\text { Erucic acid } \\
\text { markers) }\end{array}$ \\
\hline 1 & DRMR150-35XPDZ-1 & 84 & 20 & 4 & 105 & 15 & 1 \\
\hline 2 & DRMR150-35XRLC-3 & 100 & 16 & 3 & 30 & 8 & 5 \\
\hline 3 & DRMR150-35X Heera & 80 & 8 & - & - & - & - \\
\hline 4 & NRCHB101XPDZ-1 & 76 & 15 & 2 & 52 & 8 & 4 \\
\hline 5 & NRCHB101XHeera & 80 & 9 & 1 & 171 & 22 & 8 \\
\hline \multirow[t]{2}{*}{6} & NRCHB101XRLC-3 & 52 & 7 & 1 & - & - & - \\
\hline & Total no.of plants & 472 & 75 & 11 & 358 & 53 & 18 \\
\hline
\end{tabular}




\subsection{2 $\mathrm{BC}_{2} \mathrm{~F}_{1}$ generation}

Four $\mathrm{BC}_{2} \mathrm{~F}_{1}$ population developed from the cross DRMR150$35 \times \mathrm{PDZ}-1, \quad$ DRMR150-35 $\times$ RLC- $3, \quad \mathrm{NRCHB} 101 \times \mathrm{PDZ}-1$ and NRCHB101 $\times$ Heera comprise of $105,30,52$ and 171 individual plants respectively, these plants were genotyped for glucosinolate content (Table 3). Out of these 358 plants, 53 plants were found to exhibit heterozygous banding pattern among all the three markers i.e. GER-1 (Q1); At5g41 (Q3); and GER-5 (Q5)(Figure 2 and 3) These 53 plants exhibiting heterozygous banding pattern were further screened for low erucic acid trait using CAPS markers. Out of these 53 plants, 35 were having E1E1 genotype i.e. for high ER (three fragments with E1 marker while single fragment for E2 marker), none of the individual plant showed ele1 genotype i.e. for low ER (single fragment with E1 marker while three fragments for E2 marker) and 18 were E1e1 genotype i.e. intermediate ER (single fragment with E1 and E2 both the markers or three bands with E1 marker and E2 marker both)(Figure 4,5). These 18 plants which were found to exhibit heterozygotes banding pattern for FAE1.1 gene and were selected for further backcrossing with recurrent parent for generation advancement. Qu et al. (2015) performed qRT-PCR for validation of two genes(BnGRT2 and BnMYB28) associated with glucosinolate content and also identified associated SNP marker which could be useful in marker assisted breeding of low seed glucosinolate in B.napus.

The present study, aimed at validation of earlier reported markers that are PCR based and can be utilized routinely to detect the presence of high and low glucosinolate genotypes (Bisht et al., 2009) and erucic acid. These markers were used on parents, $\mathrm{BC}_{1} \mathrm{~F}_{1}$ and $\mathrm{BC}_{2} \mathrm{~F}_{1}$ progenies. The set of five markers linked to low glucosinolate trait (GER-1 (Q1); Myb28 (Q2); At5g41 (Q3); At5GAJ67 (Q4) and GER-5 (Q5) and CAPS markers (E1 and E2) got amplified in all the parents.

In present investigation as a faster screening procedure, only three molecular markers GER-1 (Q1); At5g41 (Q3); and GER-5 (Q5) were taken to screen the $\mathrm{BC}_{1} \mathrm{~F}_{1}$ and $\mathrm{BC}_{2} \mathrm{~F}_{1}$ population for low glucosinolate trait. Markers GER-1 (Q1) and GER-5 (Q5) have been already reported for screening of low glucosinolate lines in B.juncea (Singh 2010) and were validated in RIL population derived from cross between low erucic acid (Mustard-21) and a double low line(EC-597325) and also suggested their 71 percent involvement in phenotypic variance (Pushpa et al. 2015).

Markers linked to low glucosinolate taken under this study showed polymorphism among the donor and recipient parents. The amplicon size of $650 \mathrm{bp}$ was observed in case of donor genotypes namely PDZ-1, RLC-3 and Heera whereas amplicon size of 950 bp was observed in recipient genotypes NRCHB101 and DRMR150-35 with marker GER-1 linked to J2Gsl1 (BjuA. Gsl-ELONG.a)(Figure 2). Pushpa et al. (2015) also reported that low glucosinolate content lines showed amplicon size of $650 \mathrm{bp}$ and lines with high glucosinolate content show amplicon size of $950 \mathrm{bp}$. In case of marker At5g41 (Q3) linked to J9Gsl3 amplified product size of 800 bp in case of NRCHB101, DRMR150-35 whereas in case of PDZ-1, RLC-3 and Heera it was 770 bp. The third marker GER-5 linked to J3Gsl2 (BjuA. Gsl-ELONG.c, d) gave amplicon size of $310 \mathrm{bp}$ in PDZ-1, RLC-3 and Heera and 350 bp in NRCHB101 and DRMR150-35 (Figure 3). Present results are in agreement with earlier report of Pushpa et al. (2015). Ripley \& Roslinksy (2005) identified and validated molecular marker for 2-propenyl glucosinolate in B.juncea. In another study molecular evaluation for low glucosinolate content was conducted with the aid of $80 \mathrm{SSR}$ markers in B.carinata (Marquez-Lema et al. 2008). Gene-linked markers for seed glucosinolate loci were identified in B.napus genotypes by Hasan et al (2008). To predict homozygous and heterozygous individuals for FAE1.1 gene in backcross populations E1 and E2 CAPS molecular markers were used. Parents were also validated for low erucic acid trait using CAPS markers for FAE 1.1 gene namely E1 and E2 where all parental genotypes under study generated fragments of expected size for each CAPS maker and showed clear cut differentiation between low and high erucic acid genotypes. The E1 and E2 CAPS markers for FAE1.1 gene amplified 432 bp and 427 bp fragments respectively. Gupta et al. (2004) reported that FAE1.1 gene contributes more to the phenotype as compared to FAE1.2 and also verified the applicability of SNP's in marker assisted manipulation of erucic acid trait among a set of contrasting germplasm of B.juncea. Digestion of PCR amplified product of E1 molecular marker with Hpy99I enzyme resulted three fragments (one undigested fragment and two digested fragments) of $432 \mathrm{bp}, 224 \mathrm{bp}$ and $198 \mathrm{bp}$ size for high erucic acid genotypes i.e.NRCHB101, DRMR150-35 whereas in case of low erucic acid genotypes i.e. PDZ-1, RLC-3 and Heera only single undigested fragment of $432 \mathrm{bp}$ was visible (Figure $1 \mathrm{a}$ ). Reverse is the case with second CAPS molecular marker i.e.E2 under study. After digestion with BglII enzyme the low erucic acid genotypes i.e. PDZ-1, RLC-3 and Heera resulted in three fragments (one undigested fragment and two digested fragments) $427 \mathrm{bp}, 209 \mathrm{bp}$ and $198 \mathrm{bp}$ whereas only single undigested fragment of $427 \mathrm{bp}$ was visible in case of high erucic acid genotypes i.e. NRCHB101 and DRMR150-35 (Figure1 b).Confirmation of these markers linked to quality trait (low glucosinolate and low erucic acid) in all the parents leads us to further screening of $\mathrm{BC}_{1} \mathrm{~F}_{1}$ and $\mathrm{BC}_{2} \mathrm{~F}_{1}$ populations. A similar pattern of these CAPS marker upon restriction digestion was reported in a study conducted on 21 diverse genotypes of B.juncea, B.nigra and backcross population and also reported efficiency of these CAPS markers (Saini et al. 2016). The selection of CAPS was done because they are highly polymorphic between high erucic acid and low erucic acid genotypes. Bharti et al (2018) also characterized candidate genes of glucosinolate and erucic acid using SSR markers,correlated heterosis with quality traits and selected heterozygous crosses for breeding programmes. 


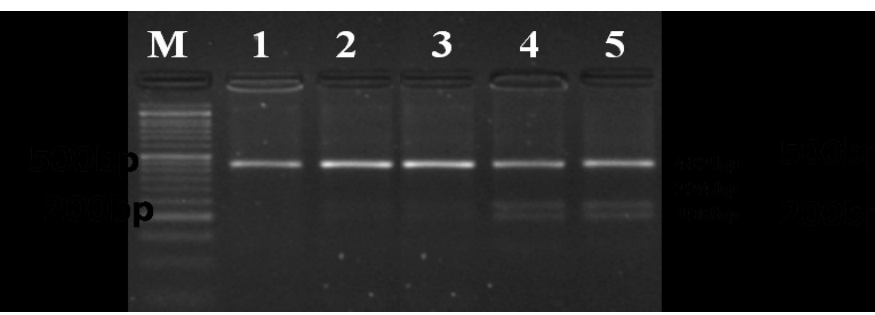

(a)

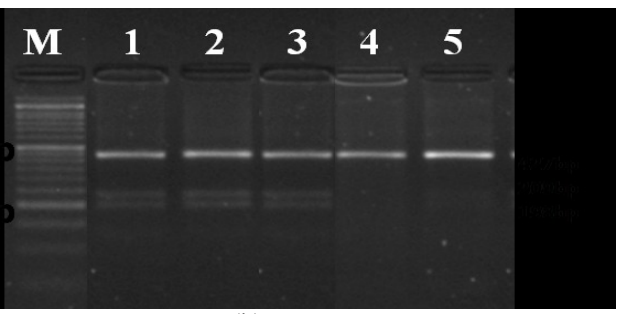

(b)

Figure 1 Agarose gel showing validation of markers linked to quality trait (Erucic acid);(a) E1 (b) E2 .M- 50bp Ladder, 1-PDZ-1 (low),2Heera (low),3-RLC-3 (low),4- NRCHB101 (high), 5-DRMR 150-35 (high).

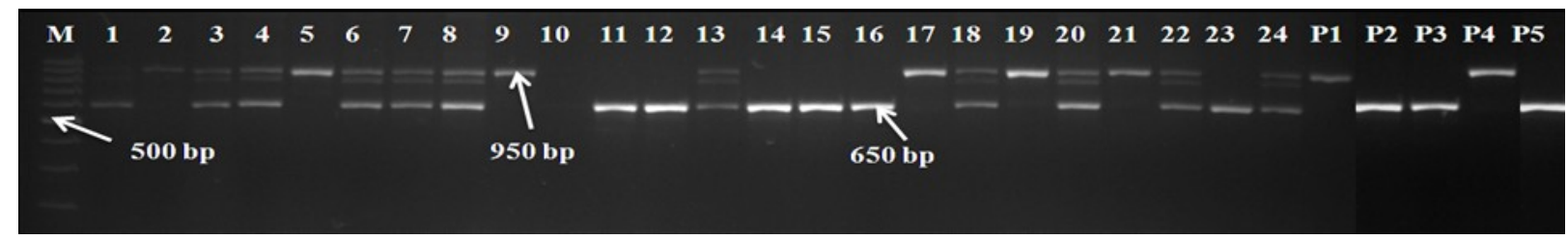

Figure 2 Agarose gel showing Validation of markers linked to quality (Glucosinolate); GER-1 (Q1) M-100bp ladder PlantNo.1-6 $\mathrm{BC}_{2}$ (DRMR150-35XPDZ-1),Plant No.7-12 BC 2 (DRMR150-35xRLC-3), Plant No.13-18 BC (NRCHB101xPDZ-1),Plant No. 19-24 BC (NRCHB101xHeera),P1-DRMR150-35,P2-HEERA,P3-PDZ-1,P4-NRCHB101 and P5-RLC-3.

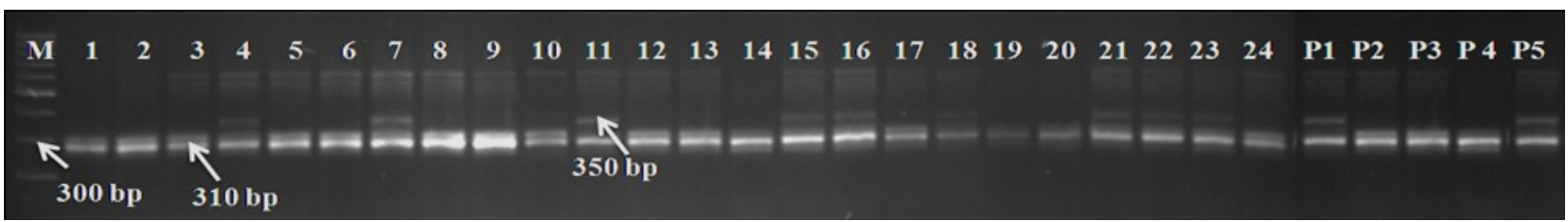

Figure 3 Agarose gel showing Validation of markers linked to quality (Glucosinolate);GER-5(Q5).M-50bp ladder Plant No.1-6

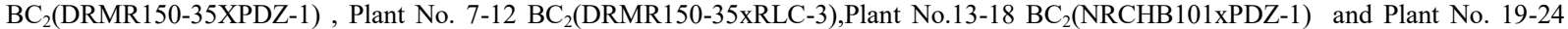
$\mathrm{BC}_{2}$ (NRCHB101xHeera),P1-DRMR150-35, P2-HEERA, P3-PDZ-1, P4-RLC-3and P5-NRCHB101.

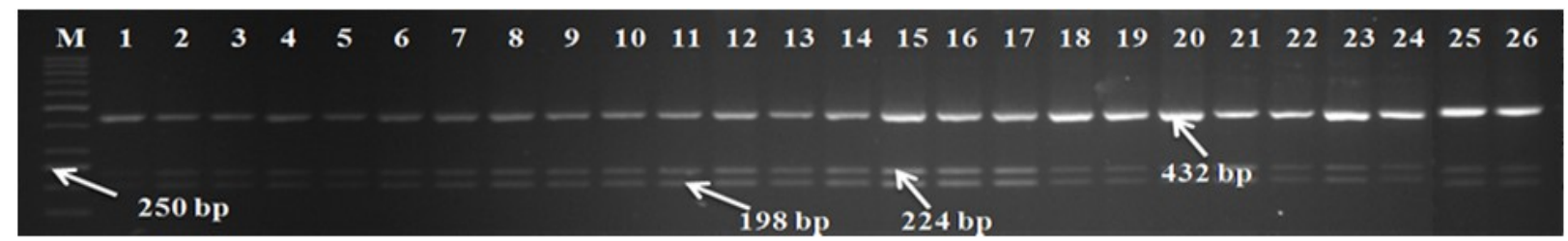

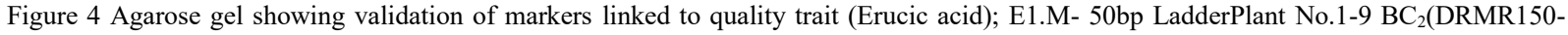
35XPDZ-1),Plant No10-19 BC 2 (DRMR150-35xRLC-3),Plant No.20-23 BC 2 (NRCHB101xPDZ-1),Plant No24-26 BC 2 (NRCHB101xHeera).

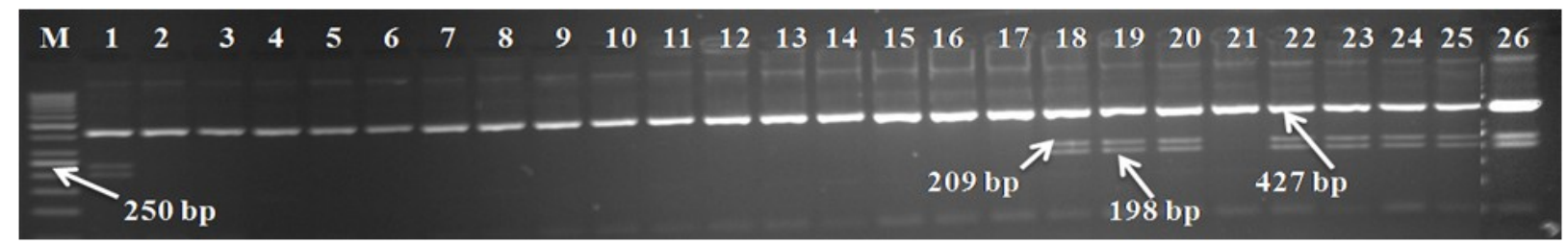

Figure 5 Agarose gel showing validation of markers linked to quality trait(Erucic acid); E2. M-50bp LadderPlant No.1-9 BC 2 (DRMR15035XPDZ-1), Plant No.10-19 BC 2 (DRMR150-35xRLC-3),Plant No.20-23 BC 2 (NRCHB101xPDZ-1), Plant No .24-26 BC 2 (NRCHB101x Heera).

Journal of Experimental Biology and Agricultural Sciences http://www.jebas.org 


\subsection{Biochemical analysis for glucosinolate and erucic acid Conflict of interest}

\section{content}

The parental lines, NRCHB101, DRMR150-35, PDZ-1, RLC-3 and Heera have total glucosinolate content $115.56 \mu \mathrm{mol} / \mathrm{g}$, $120.86 \mu \mathrm{mol} / \mathrm{g}, 19.96 \mu \mathrm{mol} / \mathrm{g}, 14.07 \mu \mathrm{mol} / \mathrm{g}$ and $33.19 \mu \mathrm{mol} / \mathrm{g}$ seed, respectively. However, the erucic acid content in seed for these parental lines was found to be $34.53 \%, 38.19 \%, 4.16 \%, 0.80 \%$ and $0 \%$ respectively.

Eleven plants of $\mathrm{BC}_{1} \mathrm{~F}_{1}$ which were found low for quality traits with molecular markers, their biochemical analysis was performed and total glucosinolate content in defatted seed meal was found in range of 68.31 to $92.36 \mu \mathrm{mol} / \mathrm{g}$ while the erucic acid content ranged from $16.67 \%$ to $30.26 \%$. Result of study revealed that there was no line in $<30-60 \mu$ mole glucosinolate/g defatted seed meal content and below $2 \%$ erucic acid content. Among the studied 11 plants,most of the plants were in range $65-85 \mu$ mole glucosinolate/g defatted seed meal. The wide range in total glucosinolate concentrations found in this study indicates that there is potential for further reduction of glucosinolate levels by screening further advanced generations. Variation in seed glucosinolate concentrations of Indian mustard have also earlier been reported by various researchers (Kumar et al., 2004; Padilla et al., 2007; Bellostas et al., 2007; Verkerk et al., 2009; Yang \& Quiros, 2010). In case of $\mathrm{BC}_{2} \mathrm{~F}_{1}$ generation samples, the total glucosinolate content was found in the range of 52.43-119.4 $\mu \mathrm{mol} / \mathrm{g}$ defatted seed meal while the erucic acid content ranged from $10.75 \%$ to $33.18 \%$. Most of the samples of backcross generations were in the range of $50-85 \mu \mathrm{mol} / \mathrm{g}$ defatted seed meal. Similar study on biochemical analysis for total glucosinolate content was conducted by Singh et al. (2018) in $F_{2}$ Generation of B. juncea and also validated using molecular markers.

\section{Conclusion}

Present study indicated effectiveness of marker assisted selection for quality traits in Indian mustard. Reported molecular markers can save time and improve the efficiency of selection. Once the nuclear background of the recurrent parent is determined, markerfacilitated progeny evaluation in successive generations will help in identification of non-segregating progenies carrying homozygous recessive alleles and thus will lead to development of high yielding double low genotypes.

\section{Acknowledgments}

Authors sincerely acknowledge ICAR, New Delhi for providing fund under CRP-Molecular breeding project and Director, DRMR for providing field and lab facilities. Thanks are also due to Incharge, IARI Regional station, Wellington for providing off season nursery facilities for generation advancement.
The authors declare that they have no conflict of interest.

\section{References}

Ackman RG, Eaton CA, Sipos JC, Loew FM, Hancock D (1977) Comparison of fatty acids from high levels of erucic acid of RSO and partially hydrogenated fish oil in non-human primate species in a short-term exploratory study. Bibliography Nutrition and Dietetics 25: 170-85

Bellostas N, Sorensen AD, Sorensen JC, Sorensen H (2007) Genetic variation and metabolism of glucosinolates. Advances in Botanical Research 45: 369- 415.

Bharti R, Chaudhary N, Sandhu R, Gupta SK, Sharma M (2018) Molecular Characterization of Candidate Gene in Glucosinolate and Erucic Acid Using SSR Markers. International Journal of Advanced Research Ideas and Innovations in Technology 4(1) : 400-409.

Bisht NC, Gupta V, Ramchiary N, Sodhi YS, Mukhopadhyay A, Arumungam N,Pental D, Pradhan AK (2009) Fine mapping of loci involved with glucosinolate biosynthesis in oilseed mustard (Brassica juncea) using genomic information from allied species; Theoretical and Applied Genetics 11: 413-421.

Chauhan JS, Singh M, Bhadauria VPS, Kumar A, Meena ML (2007) Genetic analysis of glucosinolate content in Indian mustard (Brassica juncea L.). Indian Journal of Genetics 67 (4): 411-413.

Chien K, Bellary A, Nicar M, Mukherjee A, Buja L (1983) Induction of a reversible cardiac lipidosis by a dietary long-chain fatty acid (erucic acid). Relationship to lipid accumulation in border zones of myocardial infracts. The American Journal of Pathology 112:68-77

Doyle JJ, Doyle JL (1990) Isolation of plant DNA from fresh tissue. Focus 12: 13-15.

Foolad MR, Sharma A (2005) Molecular Markers as Selection Tools in Tomato Breeding. Acta Horticulturae 695: 225-240.

Goli SAH, Sahri MM, Kadivar M (2008) Enzymatic inter esterification of structured lipids containing conjugated linoleic acid with palm stearin for possible margarine production. European Journal of Lipid Science and Technology 110:1102-1108

Gupta V, Mukhopadhyay A, Arumugam N, Sodhi YS, Pental D, Pradhan AK (2004) Molecular tagging of erucic acid trait in oilseed mustard (Brassica juncea) by QTL mapping and single nucleotide polymorphisms in FAE1 gene.Theoretical and Applied Genetics 108: 743-749. 
Hasan M, Friedt W, Pons-Kühnemann J, Freitag NM, Link K, Pushpa HD, Yadava DK, Singh N, Vasudev S, Saini N, Snowdon RJ (2008) Association of gene-linked SSR markers to Muthusamy V, Kumble P (2015) Validation of molecular markers seed glucosinolate content in oilseed rape (Brassica napus ssp. napus). Theoretical and Applied Genetics 116: 1035-1049.

Jat RS, Singh VV, Sharma P, Rai PK (2019) Oilseed brassica in India: Demand, supply, policy perspective and supply potential. Oilseeds \& fats, crops \& lipids (OCL) 26: 8.

Jesch ED, Carr TP (2017) Food ingredients that inhibit cholesterol absorption. Preventive Nutrition and Food Science 22:67-80

Kumar S, Yadav SK, Chauhan JS, Singh AK, Khan NA, Kumar PR (2004) Total glucosinolate estimation by complex formation between glucosinolate and tetrachloropalladate (II) using ELISA reader. Journal of Food Science and Technology 41: 63-65.

Liu D, Veit HP, Wilson JH, Denbow DM (2003) Long-term supplementation of various dietary lipids alters bone mineral content, mechanical properties and histological characteristics of Japanese quail. Poultry Science 82: 831-839.

Marquez-Lema A, Pérez-Vich B, Velasco-Varo L, FernándezMartínez JM (2008) Development andcharacterisation of a Brassica carinata inbred line incorporating genes for low glucosinolate content fromB. juncea.Euphytica164: 365-375.

Mattson FH, Grundy SM (1985) Comparison of effects of dietary saturated, monounsaturated, and polyunsaturated fatty acids on plasma lipids and lipoproteins in man. Journal of Lipid Research 26:194-202.

Mawlong I, Sujith Kumar M, Gurung B, Singh K, Singh D ( 2017).A simple spectrophotometric method for estimating total glucosinolates in mustard de-oiled cake. International Journal of Food Properties 20:3274-3281.

Padilla G, Cartea ME, Velasco P, De Haro A, Ordas A (2007) Variation of glucosinolates in vegetable crops of Brassica rapa. Phytochemistry 68: 536-545.

Pham LJ, Pham PJ (2012) Biocatalysed production of structured olive oil triacylglycerols.In: Boskou D (ed) Olive oil constituents, quality, health properties and bioconversion. InTech.

Priyamedha, Singh BK, Thomas L, Manju Bala, Singh VV, Singh Dhiraj (2015) Status and perspective of canola quality rapeseedmustard cultivation in India : a review. Journal of Oilseed Brassica 6: 142-151.

linked to low glucosinolate QTLs for marker assisted selection in Indian mustard (Brassica juncea L.). Indian Journal of Genetics 76:64-68

Qu CM, Li SM, Duan XJ, Fan JH, Jia LD, Zhao HY, Lu K, Li JN, $\mathrm{Xu}$ XF, Wang R (2015) Identification of Candidate Genes for Seed Glucosinolate Content Using Association Mapping in Brassica napus L. Genes (Basel) 6(4): 1215-1229.

Ramchiary N, Bisht NC, Gupta V, Mukhopadhyay A, Arumugam N, Sodhi YS, Pental D, Pradhan AK (2007) QTL analysis reveals context-dependent loci for seed glucosinolate trait in oilseed Brassica juncea: importance of recurrent selection backcross scheme for the identification of "true" QTL. Theoretical and Applied Genetics 116: 77-85.

Ripley V, Roslinsky V (2005) Marker for 2-propenyl glucosinolate content in B.juncea L. and conversion to a SCAR marker. Molecular Breeding 16:57-66.

Saini N, Singh N, Kumar A, Vihan N, Yadav S, Vasudev S, Yadava DK(2016) Development and validation of functional CAPS markers for the FAE genes in Brassica juncea and their use in marker-assisted selection. Breeding Science 66(5):831-837.

Singh J (2010) Validation and use of molecular markers tagged to low erucic acid trait for marker assisted selection in Indian mustard (Brassica juncea L.). M.Sc. thesis submitted to PG School, IARI, New Delhi.

Singh VV, Mawlong I, Dubey M, Paliwal P, Kumar MS (2018) Variability in total glucosinolate content in $F_{2}$ generation of $B$. juncea and their molecular validation. International Journal of Current Microbiology and Applied Sciences 7: 3346-3357.

Verkerk R, Schreiner M, Krumbein A, Ciska E, Holst B, Rowland I, De Schrijver R, Hansen M, Gerhäuser C, Mithen R, Dekker M (2009) Glucosinolates in Brassica vegetables: The influence of the food supply chain on intake, bioavailability and human health. Molecular Nutrition and Food Research 53: S219.

$\mathrm{Xu} \mathrm{Y,} \mathrm{Crouch} \mathrm{JH} \mathrm{(2008)} \mathrm{Marker-assisted} \mathrm{selection} \mathrm{in} \mathrm{plant}$ breeding: from publication to practice. Crop Science 48: 391-407.

Yang B, Quiros CF (2010) Survey of glucosinolate variation in leaves of Brassica rapa crops. Genetics Resources and Crop Evolution 57: 1079-1089. 